\title{
Resistance to and Accumulation of Heavy Metals by Actinobacteria Isolated from Abandoned Mining Areas
}

\author{
Soraia El Baz, ${ }^{1}$ Mohamed Baz, ${ }^{1}$ Mustapha Barakate, ${ }^{1}$ Lahcen Hassani, ${ }^{1}$ \\ Abdelhay El Gharmali, ${ }^{2}$ and Boujamâa Imziln ${ }^{1}$ \\ ${ }^{1}$ Environmental Microbiology and Toxicology Unit, Laboratory of Biology and Biotechnology of Microorganisms (LBBM), \\ Faculty of Sciences Semlalia, Cadi Ayyad University, P.O. Box 2390, 40000 Marrakech, Morocco \\ ${ }^{2}$ Laboratory of Hydrobiology, Ecotoxicology and Assainissement (LHEA), Faculty of Sciences Semlalia, Cadi Ayyad University, \\ P.O. Box 2390, 40000 Marrakech, Morocco
}

Correspondence should be addressed to Boujamâa Imziln; imziln@uca.ma

Received 7 August 2014; Revised 13 November 2014; Accepted 18 November 2014

Academic Editor: Wen-Jun Li

Copyright (C) 2015 Soraia El Baz et al. This is an open access article distributed under the Creative Commons Attribution License, which permits unrestricted use, distribution, and reproduction in any medium, provided the original work is properly cited.

\begin{abstract}
Accumulation of high concentrations of heavy metals in environments can cause many human health risks and serious ecological problems. Nowadays, bioremediation using microorganisms is receiving much attention due to their good performance. The aim of this work is to investigate heavy metals resistance and bioaccumulation potential of actinobacteria strains isolated from some abandoned mining areas. Analysis of mining residues revealed that high concentration of zinc "Zn" was recorded in Sidi Bouatman, Arbar, and Bir Nhass mining residues. The highest concentration of lead "Pb" was found in Sidi Bouatman. Copper "Cu," cadmium "Cd," and chromium "Cr" were found with moderate and low concentrations. The resistance of 59 isolated actinobacteria to the five heavy metals was also determined. Using molecular identification $16 \mathrm{~S}$ rRNA, these 27 isolates were found to belong to Streptomyces and Amycolatopsis genera. The results showed different levels of heavy metal resistance; the minimum inhibitory concentration (MIC) recorded was 0.55 for $\mathrm{Pb}, 0.15$ for $\mathrm{Cr}$, and $0.10 \mathrm{mg} \cdot \mathrm{mL}^{-1}$ for both $\mathrm{Zn}$ and $\mathrm{Cu}$. Chemical precipitation assay of heavy metals using hydrogen sulfide technic (H2S) revealed that only 27 isolates have a strong ability to accumulate $\mathrm{Pb}$ (up to $600 \mathrm{mg}$ of $\mathrm{Pb}$ per $\mathrm{g}$ of biomass for Streptomyces sp. BN3).
\end{abstract}

\section{Introduction}

Heavy metal pollution is one the most important environmental problems in marine, terrestrial, and freshwater areas [1]. They can be accumulated in the human body through food webs, thereby promoting chronic and acute disorder and creating obviously serious health problems $[2,3]$. The anthropogenic sources of metal contamination can be divided into five main groups: (i) metalliferous mining and smelting, (ii) industries, (iii) atmospheric deposition, (iv) agriculture, and (v) waste disposal $[4,5]$. Industries bearing heavy metals, such as $\mathrm{Pb}, \mathrm{Zn}, \mathrm{Cr}, \mathrm{Cd}, \mathrm{Cu}, \mathrm{As}$, and $\mathrm{Ni}$, are a major concern because they are well known to produce a long-term negative impact on soil and water in the surrounding environment $[6,7]$.

Conventional technologies for removing metals from industrial effluents, such as chemical precipitation, chemical oxidation or reduction, ion exchange, membrane filtration, electrochemical treatment, reverse osmosis, and evaporation, were frequently used. These processes may be ineffective or extremely expensive [8]. Nowadays, new processes, based on microorganism technology like bioaccumulation and biosorption, have been investigated for the developments of cheaper and more effective technologies in order to decrease the amount of industrial wastewater produced and to improve the quality of the treated effluent. A wide variety of microorganisms, for example, bacteria, yeast, algae, protozoa, and fungi, have developed the capabilities to protect themselves from heavy metal toxicity by various mechanisms such as uptake, oxidation, adsorption, methylation, and reduction [4]. It was also reported that some bacteria can use mechanisms of tolerance and detoxification of heavy metals and still produce chelating agents that bound metals and reduce their toxicity [9]. Many living bacteria have been reported to 


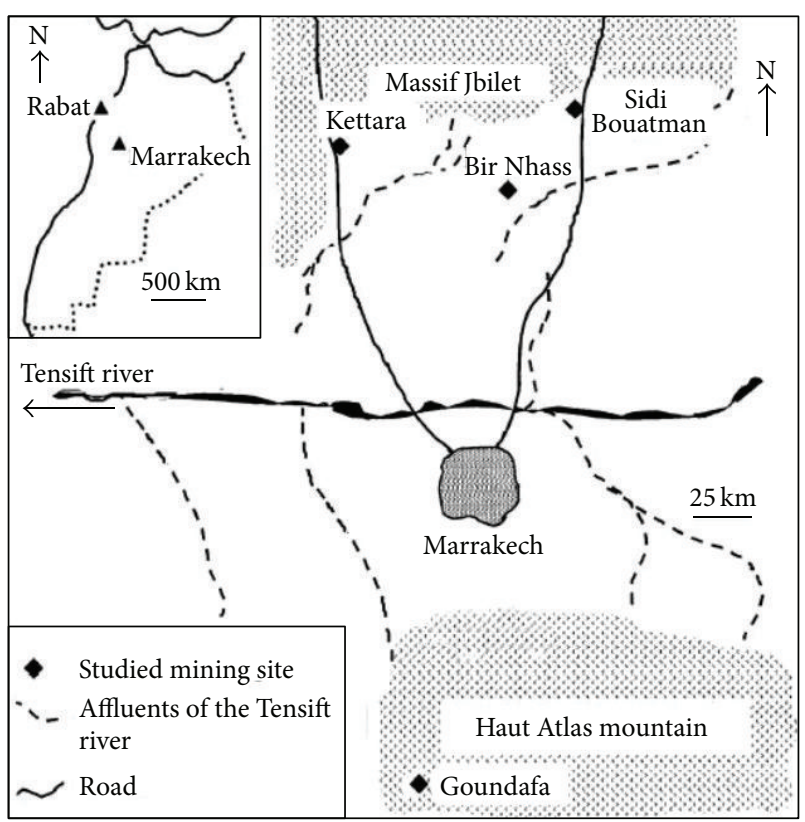

FIGURE 1: Localisation of prospected abandoned mining areas of Marrakech, Morocco: Kettara, Sidi bouatman, Bir Nhass, and Goundafa.

reduce or to transform toxic contaminants into their less toxic forms. Actinobacteria constitute a morphologically diverse group of Gram-positive bacteria, with high metabolic versatility [10]. As reported earlier, actinomycetes are the good bioremediation [11-16]. Their metabolic diversity, particular growth characteristics, mycelial form, and relatively rapid ability to colonize selective substrates make them well-suited for use as agents for bioremediation of inorganic and organic compounds [16-20].

Industrial and mining activities are important for economic development, especially in many developing countries as Morocco. However, these activities also represent the main sources of heavy metal contamination.

In Marrakech region, many exploitation metal mines have ceased to be functional many years ago. Mining residues were abandoned in open air without any treatment and were exposed to the atmospheric hazards. In fact, these release heavy metals and other pollutants to the drainage and represent a potential danger of surrounding terrestrial and aquatic ecosystems. Moreover these mining sites are generally situated near agricultural zones [21].

To our knowledge, little research had been done regarding the problematic of mining residues in our country, despite awareness of health and environmental risks that they may cause.

In the present study we are interested in mining residues collected from various abandoned mining areas located around Marrakech region, West Central Morocco (Figure 1). Kettara mine (KT) is located approximately $30 \mathrm{~km}$ NorthWest of Marrakech and was operated for pyrrhotine extraction until 1981 [22]. Sidi Bouatman mine (SB) is located approximately $33 \mathrm{~km}$ north of Marrakech and was operated for $\mathrm{Pb}, \mathrm{Zn}$, and pyrite extraction until 1980. The old Bir
Nhass zinc mine $(\mathrm{BN})$ is located approximately $30 \mathrm{~km}$ north of Marrakech; it was closed at the end of the 20th century. Goundafa mine, located approximately at $90 \mathrm{~km}$ south of Marrakech, operated for $\mathrm{Pb}, \mathrm{Zn}$, and $\mathrm{Cu}$ extraction and in 1989 the mine has ceased to be functional. In Goundafa area, samples were collected from two sites Arbar plant (GA) and Tenfit Mine (GT).

The aim of the present work deals with the evaluation of the contamination levels of mining residues, the isolation of heavy metals resistant actinobacteria, their potential capacity to accumulate heavy metals $(\mathrm{Pb}, \mathrm{Cu}, \mathrm{Zn}, \mathrm{Cd}$, and $\mathrm{Cr})$, and both morphological and molecular characterization of resistant and accumulating isolated strains.

\section{Materials and Methods}

2.1. Total Concentration of Heavy Metals of Mining Residues Samples. The $\mathrm{pH}$ and the electrical conductivity (EC) for each mining residue sample were measured according to AFNOR X31-103 [23] and [24], respectively. The total concentrations of $\mathrm{Zn}, \mathrm{Pb}, \mathrm{Cd}, \mathrm{Cu}$, and $\mathrm{Cr}$ were determined for all sample residues [23]. Samples were oven-dried at $500^{\circ} \mathrm{C}$, finely ground $(2 \mathrm{~mm})$, and then ashed in a crucible. $5 \mathrm{~mL}$ of fluohydric acid (50\%) was added to $0.5 \mathrm{~g}$ of each sample and brought to dry. Samples were then digested with aqua regia $\left(\mathrm{HCl}\right.$ and $\mathrm{HNO}_{3}$, successively, in a ratio of $\left.3: 1\right)$. Flasks, containing samples, were heated gently until the samples were digested, which is indicated by the formation of a clear solution above the residue. This solution was adjusted to $10 \mathrm{~mL}$ with distilled water. Digested mining residues samples were analyzed for metals concentrations $\left(\mathrm{Pb}^{2+}, \mathrm{Cu}^{2+}, \mathrm{Zn}^{2+}\right.$, $\mathrm{Cr}^{6+}$, and $\mathrm{Cd}^{2+}$ ) using an UNICAM 929 model flame atomic absorption spectrophotometer (FAAS).

2.2. Isolation of Actinobacteria from Mining Residues. Ten grams of the residues sample were suspended in $100 \mathrm{~mL}$ of sterile distilled water and shaken vigorously for $10 \mathrm{~min}$. Aliquots $(0.1 \mathrm{~mL})$ of appropriate dilutions were plated on Bennett's agar medium [25]. Plates were incubated at $30^{\circ} \mathrm{C}$ for 15 days. The isolation and purification of actinobacteria were done by repeated streaking and dilution-plate techniques using Bennett's agar medium. All isolates were then maintained in glycerol $20 \%$ at $-20^{\circ} \mathrm{C}$.

\subsection{Selective Medium for the Metal-Resistant Actinobacteria.} In order to choose the appropriate medium to select the metal resistant actinobacteria, two media were used, nutrient agar (type Pronadisa), and modified Duxbury agar (KCl: $0.3 \mathrm{~g} \cdot \mathrm{l}^{-1}$; $\mathrm{CaCl}_{2}: 0.025 \mathrm{~g} \cdot \mathrm{l}^{-1} ; \mathrm{MgSO}_{4} \cdot 7 \mathrm{H}_{2} \mathrm{O}: 0.2 \mathrm{~g} \cdot \mathrm{l}^{-1} ; \quad\left(\mathrm{NH}_{4}\right)_{2} \mathrm{SO}_{4}$ : $0.5 \mathrm{~g} \cdot \mathrm{l}^{-1}$; glucose: $1 \mathrm{~g} \cdot \mathrm{l}^{-1}$; tryptone: $1 \mathrm{~g} \cdot \mathrm{l}^{-1}$; yeast extract: $0.5 \mathrm{~g} \cdot \mathrm{l}^{-1}$; agar: $\left.15 \mathrm{~g} \cdot \mathrm{l}^{-1}\right)$, the $\mathrm{pH}$ of the medium was adjusted to 7.00 [26]. Tested metals were: lead $\left[\mathrm{Pb}\left(\mathrm{NO}_{3}\right)_{2}\right]$; copper $\left[\mathrm{Cu}\left(\mathrm{NO}_{3}\right)_{2} \cdot \mathrm{H}_{2} \mathrm{O}\right]$; cadmium $\left[\mathrm{Cd}\left(\mathrm{NO}_{3}\right)_{2} \cdot 4 \mathrm{H}_{2} \mathrm{O}\right]$; chromium $\left[\mathrm{K}_{2} \mathrm{Cr}_{2} \mathrm{O}_{7}\right]$ and zinc $\left[\mathrm{Zn}\left(\mathrm{NO}_{3}\right)_{2} \cdot 6 \mathrm{H}_{2} \mathrm{O}\right]$. Stock solutions of metals salts, prepared in distilled water were sterilized by filtration $(0.20 \mu \mathrm{m}) \cdot 0.05 \mathrm{mg} \cdot \mathrm{mL}^{-1}$ of each heavy metal was used in both media (nutrient agar and Duxbury agar). Plates were incubated at $30^{\circ} \mathrm{C}$ for 7 days. Growth of actinobacteria 
on culture media containing no metals was used as control.

2.4. Screening of Heavy Metal Resistant Actinobacteria. Heavy metal resistance of all actinobacteria isolated from mining residues was assessed against five elements $(\mathrm{Pb}, \mathrm{Cu}, \mathrm{Zn}, \mathrm{Cd}$, and $\mathrm{Cr})$ in triplicate with different concentrations $(0.05,0.15$, 0.25 , and $1 \mathrm{mg} \cdot \mathrm{mL}^{-1}$ ) in Duxbury agar. Growth percentages were calculated for each metal after comparison with controls.

To determine the MIC of each metal, actinobacteria isolates were grown in Duxbury agar with increased concentrations. The MIC was defined as the lowest concentration of the metal inhibiting the visible growth of the bacteria.

2.5. Screening of Heavy Metal-Accumulating Actinobacteria. Actinobacterial isolates were streaked on Duxbury agar plates containing $0.05 \mathrm{mg} \cdot \mathrm{mL}^{-1}$ of each tested metal. After incubation, plates were exposed to hydrogen sulfide gas in a sealed container (resulting from the reaction of $\mathrm{Na}_{2} \mathrm{~S}$ with $\mathrm{HCl}$ ). Simple and effective formation of dark precipitate was achieved for several metals by treatment with sulfide. Upon formation of the metal sulfide, plates were carefully screened to detect any change in the region surrounding bacteria colonies [27].

In order to determine metal quantities accumulated by isolates, actinobacteria strains were cultured on Bennett liquid medium without heavy metals. After incubation $\left(30^{\circ} \mathrm{C}\right.$ for 7 days), cultures were centrifuged at $12,000 \mathrm{rpm}$ for $20 \mathrm{~min}$; the pellets were washed twice with phosphatebuffered saline and were resuspended in sterile solutions containing $0.5 \mathrm{mg} \cdot \mathrm{mL}^{-1}$ of tested metal. The tubes were then incubated at room temperature in a roller mixer. After $3 \mathrm{~h}$ of incubation, the cells were harvested by centrifugation at $12,000 \mathrm{rpm}$ for $20 \mathrm{~min}$. The amount of residual metal present in the supernatant was measured by an atomic absorption spectrophotometer. At the same time, dry weight of the bacterial pellet was determined. Values are expressed as the averages of three determinations carried out in parallel. Bioaccumulation of the metal in the biomass was expressed as the amount removed from solution containing the tested metal based on the following equation [3]:

$$
\text { Metal removal }=\frac{\left[C_{0}-C_{t}\right] V}{M},
$$

where $C_{0}$ is metal initial concentration in the solution $\left(\mathrm{mg} \cdot \mathrm{mL}^{-1}\right) ; C_{t}$ is metal concentration after $3 \mathrm{~h}$ in the solution $\left(\mathrm{mg} \cdot \mathrm{mL}^{-1}\right) ; V$ is total volume of the culture, and $M$ is dry mass of biomass (g).

2.6. Morphological and Physiological Characterization of Actinobacteria Isolates. The morphological, cultural, physiological, and biochemical characteristics of the selected isolates were evaluated as described by Shirling and Gottlieb [28]. Cultural characteristics were observed on glycerolasparagine agar (ISP5), inorganic salts-starch agar (ISP4), tryptone-yeast extract agar (ISP1), and yeast extract-malt extract agar (ISP2) media at $30^{\circ} \mathrm{C}$ for $7-21$ days. Melanin production was detected by growing the isolates on peptoneyeast extract-iron agar (ISP6) [28]. The substrate mycelium color was identified in terms of Prauser's guide 7 [29]. The assimilation of carbohydrates was studied by using the medium ISP9, containing 13 different carbohydrates at a concentration of $1 \%(\mathrm{w} / \mathrm{v})$ as sole carbon source.

2.7. Molecular Identification of Actinobacteria Isolates. The DNA of selected actinobacteria was isolated according to the procedure described by Hopwood et al. [30]. The $16 \mathrm{~S}$ rDNA was amplified using the PCR method with Taq DNA polymerase and primers 27F (5'-AGAGTTTGATCMTGGCTCAG- $3^{\prime}$ ) and 1492R ( $5^{\prime}$-TACGGYTACCTTGTTACGACTT- $3^{\prime}$ ) [31]. The conditions for thermal cycling were as follows: denaturation of the target DNA at $98^{\circ} \mathrm{C}$ for $3 \mathrm{~min}$ followed by 30 cycles at $94^{\circ} \mathrm{C}$ for $1 \mathrm{~min}$, primer annealing at $52^{\circ} \mathrm{C}$ for $1 \mathrm{~min}$, and primer extension at $72^{\circ} \mathrm{C}$ for $5 \mathrm{~min}$. At the end of the cycling, the reaction mixture was held at $72^{\circ} \mathrm{C}$ for $5 \mathrm{~min}$ and then cooled to $4^{\circ} \mathrm{C}$. The PCR product obtained was sequenced using an automated sequencer and the same primers as above for sequence determination (Macrogen Inc. (Seoul, Korea)). The sequence was compared for similarity with the reference species of bacteria contained in genomic database banks, using the NCBI Blast available at http://www.ncbi.nlm.nih.gov/. A phylogenetic tree based on $16 \mathrm{~S}$ rRNA gene sequence was constructed with the neighborjoining algorithm in MEGA version 5 [32].

2.8. Siderophore Assays. The universal chemical assay of Schwyn and Neilands [33] was used for detecting siderophore production by actinobacteria using Chrome Azurol S agar assay (CAS). For this experiment, glasswares were first cleaned by immersion in dichromate-acid solution for $48 \mathrm{~h}$ and then rinsed several times with distilled water before use. In parallel, a minimum medium agar (MM) without iron (glucose: $10 \mathrm{~g} \cdot \mathrm{l}^{-1} ; \mathrm{KNO}_{3}: 1 \mathrm{~g} \cdot \mathrm{l}^{-1} ; \mathrm{MgSO}_{4}: 0.5 \mathrm{~g} \cdot \mathrm{l}^{-1} ; \mathrm{KCl}$ : $0.5 \mathrm{~g} \cdot \mathrm{l}^{-1} ; \mathrm{K}_{2} \mathrm{HPO}_{4}: 0.5 \mathrm{~g} \cdot \mathrm{l}^{-1}$; agar: $15 \mathrm{~g} \cdot \mathrm{l}^{-1}$ ) was prepared. Pure strains of actinobacteria were grown on MM for 3 days at $30^{\circ} \mathrm{C}$ and then mycelia plugs $(9 \mathrm{~mm}$ in diameter) were cut, placed on CAS agar plates, and incubated for 3 days at $30^{\circ} \mathrm{C}$. As control, MM was amended with $0.01 \mathrm{~g} \cdot \mathrm{l}^{-1}$ of $\mathrm{FeSO}_{4} \cdot 7 \mathrm{H}_{2} \mathrm{O}$. A positive reaction is indicated by a color change of CAS reagent from blue to orange, leading to a clearly visible yellow-orange halo around the disk.

Hydroxamate-specific assay was used to reveal the presence of hydroxamate siderophores in culture supernatants. Siderophore production was monitored by ferric-catalyzed acid hydrolysis and Csaky assay [34]. Strains producing siderophores were inoculated on liquid minimum medium MM. The cultures were incubated for 2 weeks and then centrifuged at $4000 \mathrm{rpm}$ for $20 \mathrm{~min}$ at $4^{\circ} \mathrm{C}$. the supernatant $(2 \mathrm{~mL})$ was put in a test tube. This sample was saturated with ferric ion, and a $0.2 \mathrm{~mL}$ aliquot was hydrolyzed with $2 \mathrm{~mL}$ of $3 \mathrm{M}$ sulfuric acid for $4 \mathrm{~h}$ in a $120^{\circ} \mathrm{C}$ (autoclave). Sodium acetate $(2 \mathrm{M} ; 7 \mathrm{~mL})$ and sulfanilamide $(2 \mathrm{~mL}$ of a $1 \%[\mathrm{w} / \mathrm{v}]$ solution in $30 \%[\mathrm{v} / \mathrm{v}]$ acetic acid) were added, and the $\mathrm{pH}$ was adjusted to $3.1 \pm 0.1$. This sample was oxidized with iodine ( $2 \mathrm{~mL}$ of $0.0325 \%[\mathrm{w} / \mathrm{v}] \mathrm{I}_{2}$ in $0.05 \%[\mathrm{w} / \mathrm{v}] \mathrm{KI}$ ) for $4 \mathrm{~min}$ at 
TABLE 1: Mean heavy metal concentrations, $\mathrm{pH}$, and conductivity in mining residues samples.

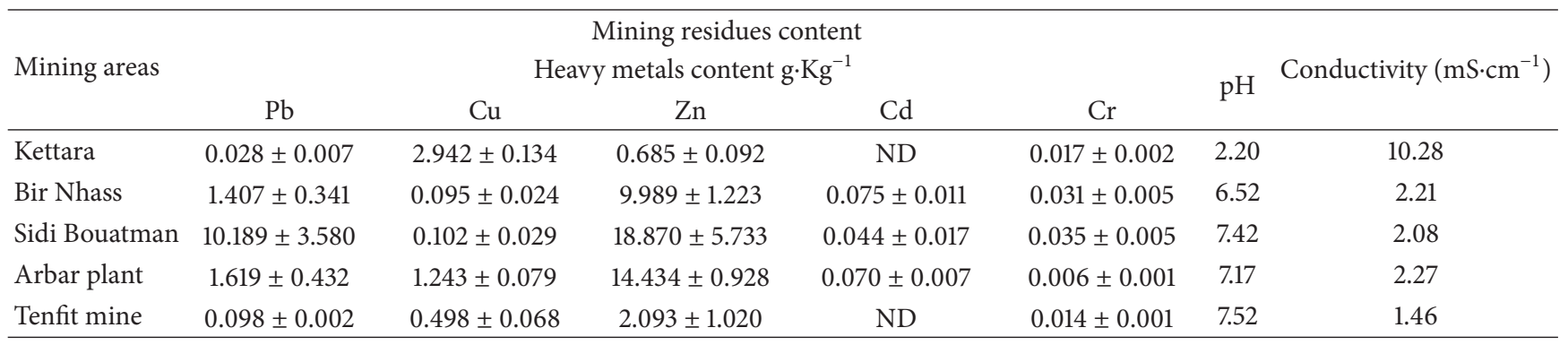

*ND: not detected.

room temperature $\left(24^{\circ} \mathrm{C}\right)$. Excess iodine was removed by the addition of sodium arsenite $(2 \mathrm{~mL}$ of a $0.075 \%[\mathrm{w} / \mathrm{v}]$ solution in distilled water). $\mathrm{N}$-(1-Naphthyl)ethylenediamine $(2 \mathrm{~mL}$ of a $0.05 \%[\mathrm{w} / \mathrm{v}]$ solution in distilled water) was added, and the mixture was allowed to stand for $30 \mathrm{~min}$ to complete the color development. The solution was diluted to $50 \mathrm{~mL}$, and the $A_{543}$ was measured. A blank was prepared by addition of the reagents to $0.2 \mathrm{~mL}$ of distilled water.

The presence of catechol siderophores was also investigated in culture supernatants using a modified version of the Arnow reaction $[35,36]$. In this assay, the test sample is treated with $\mathrm{HCl}, \mathrm{NaNO}_{2}$, and $\mathrm{Na}_{2} \mathrm{MoO}_{4}-2 \mathrm{H}_{2} \mathrm{O}$, which results in a yellow color; subsequent addition of $\mathrm{NaOH}$ causes the color to change to red in the presence of catechol compounds. Reagents were prepared and reactions carried out as in Neilands and Nakamura [36]; absorbance values were determined using a spectrophotometer at a wavelength of $515 \mathrm{~nm}$.

2.9. Statistical Analysis. All experiments were performed in triplicate. To compare differences in metal accumulation among tested isolates, obtained data were analyzed through multivariate analysis of variance (ANOVA), and the means were compared by Tukey multiple range test. All numeric differences in the data were considered significantly different at the probability level of $P \leq 0.05$.

\section{Results}

3.1. Assessment of Present Mining Residues Heavy Metal Concentrations. The mean metal concentration (in $\mathrm{g} \cdot \mathrm{Kg}^{-1}$ ) in all prospected mining residues and their related statistical parameters is shown in Table 1 . Heavy metal concentrations did show variation between sites. At Sidi Bouatman site, $\mathrm{Pb}$ and $\mathrm{Zn}$ were the dominant elements with 10.19 and $18.87 \mathrm{~g} \cdot \mathrm{Kg}^{-1}$, respectively. While At Arbar plant, the dominant element was $\mathrm{Zn}$ with $14.43 \mathrm{~g} \cdot \mathrm{Kg}^{-1}$. In Kettara mine, $\mathrm{Cu}$ was found to be the dominant metal with $2.94 \mathrm{~g} \cdot \mathrm{Kg}^{-1}$; for Bir Nhass, $\mathrm{Zn}$ with $9.99 \mathrm{~g} \cdot \mathrm{Kg}^{-1}$, and at Tenfit mine, the higher concentration of the dominant metal $(\mathrm{Zn})$ reached $2.09 \mathrm{~g} \cdot \mathrm{Kg}^{-1}$. Mean concentrations of $\mathrm{Cr}$ and $\mathrm{Cd}$ were significantly lower than the other tested metals in all sites. For the $\mathrm{pH}$ and conductivity values, there were no significant variations between the four sites (Bir Nhass, Sidi Bouatman, Arbar plant, and Tenfit mine), while a significant decrease

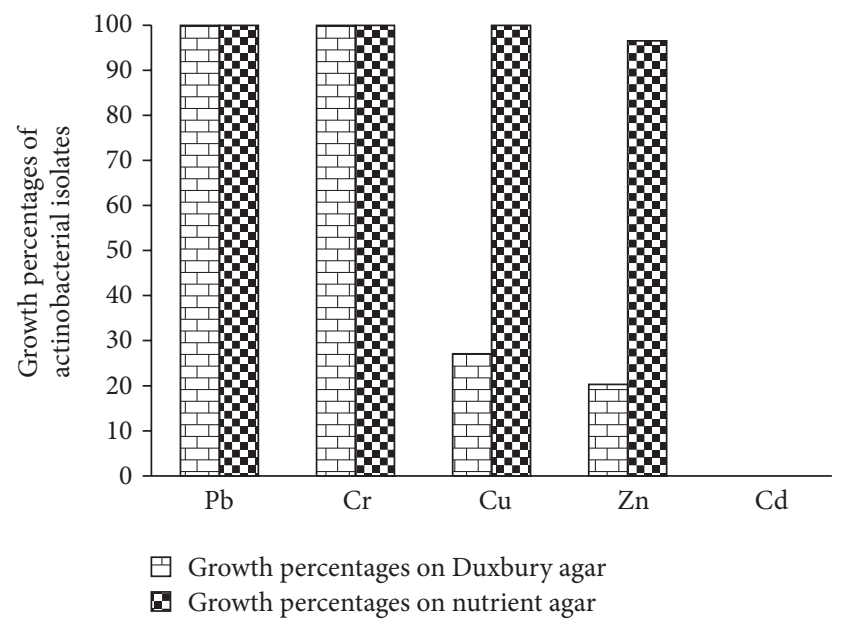

FIGURE 2: Growth percentages of actinobacterial isolates on both Duxbury agar and nutrient agar with: $\mathrm{Pb}, \mathrm{Cu}, \mathrm{Zn}, \mathrm{Cd}$, and $\mathrm{Cr}$ at the concentration $0.05 \mathrm{mg} \cdot \mathrm{mL}^{-1}$ (the percentage of growth was calculated compared to the control).

in $\mathrm{pH}$ values (2.2) and a significant increase in conductivity $\left(10.28 \mathrm{mS} \cdot \mathrm{cm}^{-1}\right)$ were recorded in Kettara site.

3.2. Isolation of Actinobacteria and Screening of MetalResistant Strains. A total of 59 actinobacteria strains were isolated from mining residues located in different mining areas around Marrakech city ( $\mathrm{BN}, 30$ isolates; $\mathrm{SB}, 8$ isolates; and GT, 21 isolates). No actinobacteria strain was isolated from Kettara and Arbar sites.

Bacterial resistance to heavy metals was performed in two culture media (nutrient agar and modified Duxbury agar). Obtained results shown in Figure 2 indicate differences in growth of strains, in both media amended or not with heavy metals $(\mathrm{Cd}, \mathrm{Cu}, \mathrm{Pb}, \mathrm{Zn}$, and $\mathrm{Cr})$. In the presence of metals, growth of tested isolates on Duxbury agar was very low in comparison with nutrient agar. On Duxbury agar supplemented with metals, the growth percentages reached $100 \%$ for $\mathrm{Pb}$, and $\mathrm{Cr}$, while the growth percentage did not exceed $28 \%$ for $\mathrm{Cu}$ and $21 \%$ for $\mathrm{Zn}$. On nutrient agar, these percentages were found to be equal to $100 \%$ for $\mathrm{Pb}, \mathrm{Cu}$, and $\mathrm{Cr}$ and $96.61 \%$ for $\mathrm{Zn}$. From these results, it seems clear that Duxbury agar did not affect or affects slightly the biodisponibility of metal in the culture medium. 
TABLE 2: Heavy metals tolerance in actinobacteria from mining areas.

\begin{tabular}{|c|c|c|c|c|c|c|}
\hline \multirow{2}{*}{ Mining areas } & \multirow{2}{*}{ Strains } & \multicolumn{5}{|c|}{ Heavy metals $\mathrm{mg} \cdot \mathrm{mL}^{-1}$} \\
\hline & & $\mathrm{Pb}$ & $\mathrm{Cu}$ & $\mathrm{Zn}$ & $\mathrm{Cr}$ & $\mathrm{Cd}$ \\
\hline \multirow{10}{*}{ Tenfit mine } & GT6, GT15, GT39 & 0.25 & 0.10 & 0.10 & 0.15 & - \\
\hline & GT14, GT41 & 0.10 & 0.10 & 0.10 & 0.10 & - \\
\hline & GT1 & 0.25 & 0.10 & - & 0.15 & - \\
\hline & GT2, GT38 & 0.25 & 0.10 & - & 0.10 & - \\
\hline & GT44 & 0.20 & 0.10 & - & 0.10 & - \\
\hline & GT12, GT13, GT3 & 0.10 & 0.10 & - & 0.10 & - \\
\hline & GT4, GT10 & 0.30 & - & - & 0.10 & - \\
\hline & GT40 & 0.25 & - & - & 0.10 & - \\
\hline & GT5 & 0.20 & - & - & 0.10 & - \\
\hline & GT7, GT8, GT9, GT11 & 0.10 & - & - & 0.10 & - \\
\hline \multirow{3}{*}{ Sidi Bouatman } & SB20, SB21 & 0.30 & 0.10 & 0.10 & 0.10 & - \\
\hline & SB16, SB18, SB30, SB31 & 0.30 & - & 0.10 & 0.15 & - \\
\hline & SB19, SB22 & 0.30 & - & - & 0.15 & - \\
\hline \multirow{6}{*}{ Bir nhass } & BN26 & 0.30 & 0.10 & 0.10 & 0.15 & - \\
\hline & $\mathrm{BN} 2$ & 0.55 & - & - & 0.15 & - \\
\hline & BN5, BN9, BN12, BN23, BN46, BN56, BN69, BN71, BN82 & 0.30 & - & - & 0.15 & - \\
\hline & $\mathrm{BN} 3, \mathrm{BN} 4, \mathrm{BN} 13, \mathrm{BN70}, \mathrm{BN72,} \mathrm{BN73}$ & 0.30 & - & - & 0.10 & - \\
\hline & BN7, BN17, BN22, BN24, BN25, BN27, BN28, BN29, BN68 & 0.25 & - & - & 0.10 & - \\
\hline & BN47, BN48, BN57, BN58 & 0.20 & - & - & 0.10 & - \\
\hline
\end{tabular}

(一): no tolerant strains.

For this reason, we have chosen Duxbury medium as a suitable medium to select heavy metals resistant actinobacteria.

Resistance of 59 actinobacteria isolates to the five heavy metals ( $\mathrm{Pb}, \mathrm{Cu}, \mathrm{Cd}, \mathrm{Zn}$, and $\mathrm{Cr}$ ) was run, and $\mathrm{MIC}$ values were listed in Table 2. According to the obtained data, maximal MIC values were $0.55 \mathrm{mg} \cdot \mathrm{mL}^{-1}$ for $\mathrm{Pb}, 0.15 \mathrm{mg} \cdot \mathrm{mL}^{-1}$ for $\mathrm{Cr}$ and $0.1 \mathrm{mg} \cdot \mathrm{mL}^{-1}$ for $\mathrm{Zn}$, and $\mathrm{Cu}$ for $\mathrm{Cd}$; no strain was found to be resistant.

From data in Table 3, differences in heavy metal toxicity levels against the tested strains were reported. One hundred percent of the tested strains were capable to grow in the presence of $\mathrm{Pb}$ and $\mathrm{Cr}$ at $0.05 \mathrm{mg} \cdot \mathrm{mL}^{-1}$. However, in the presence of $\mathrm{Cu}$ and $\mathrm{Zn}$ at the same concentration, only 30.08 and $34.05 \%$ of actinobacteria strains were able to grow, respectively. For lead, the percentage of resistant bacteria decreased with the increase of its concentration in the medium. When concentration of $\mathrm{Pb}$ reached $0.25 \mathrm{mg} \cdot \mathrm{mL}^{-1}$, the percentage of resistant strains decreased to $55.40 \%$, and the growth was completely stopped at $1 \mathrm{mg} \cdot \mathrm{mL}^{-1}$. For Copper, Zinc, and Chromium, actinobacterial growth was completely repressed for concentrations greater or equal to $0.15 \mathrm{mg} \cdot \mathrm{mL}^{-1}$.

From these results, lead may be the most tolerated metal by our selected strains, and cadmium was the most toxic one. Chromium, zinc, and copper gave intermediate results. In this report, we have also noted that resistance percentages to $\mathrm{Pb}$, $\mathrm{Zn}$ and $\mathrm{Cr}$ among strains isolated from Sidi Bouatman site (Tables 2 and 3), were higher compared to isolates from other sites. We can conclude that the resistance levels depended on the site of strains isolation.
3.3. Screening of Heavy Metal-Accumulating Actinobacteria. According to the finding results, 27 of the total isolates were found to be able to accumulate lead on lead-Duxbury agar. We notice the presence of a clear halo around the colony (Figure 3), which shows the disappearance of metal and this may be due to its accumulation by the strain. But none of strains was seen to play some accumulation capacities against $\mathrm{Cu}, \mathrm{Cd}, \mathrm{Cr}$, or $\mathrm{Zn}$.

Accumulated quantity results of lead by actinobacterial tested strains are shown in Figure 4. Among the twenty seven tested strains, the amount of accumulated lead ranged from $12.98 \mathrm{mg} \cdot \mathrm{g}^{-1}$ (BN7) to $615.04 \mathrm{mg} \cdot \mathrm{g}^{-1}$ (BN3). According to statistical analysis, there was a significant difference $(P \leq$ 0.05 ) between the accumulation capacity results, and this difference may depend on tested strain.

3.4. Taxonomic and Molecular Identification of the Actinobacterial Isolates. Selected isolates (27 strains) were tested for taxonomical diversity using morphological, cultural, physiological, and biochemical criteria as well as other features (Table 4). The aerial and substrate mycelium colors were determined on ISP2, ISP4, and ISP5 media. Tested strains showed different abilities to assimilate 13 carbon sources (Table 4). The analysis of 16S rRNA gene sequence of these strains (Table 5 and Figure 6) confirmed this classification. Phylogenetic tree, based on 16S rRNA gene, clearly demonstrated that the majority of selected isolates belong to Streptomyces genus and only three isolates (GT6, GT15, and GT39) were found belonging to Amycolatopsis genus.

The 16S rRNA sequence was deposited in GenBank under accession numbers: KF479164, KF479165, KF479166, 
TABLE 3: Growth percentages of actinobacteria isolated from mining areas.

\begin{tabular}{|c|c|c|c|c|c|c|}
\hline \multirow[b]{2}{*}{ Heavy metal } & \multirow[b]{2}{*}{ Mining areas } & \multirow[b]{2}{*}{ Number of actinobacteria isolated } & \multicolumn{4}{|c|}{ Concentration of heavy metals } \\
\hline & & & $\begin{array}{c}0.05 \\
\mathrm{mg} \cdot \mathrm{mL}^{-1^{\mathrm{a}}}\end{array}$ & $\begin{array}{c}0.15 \\
\mathrm{mg} \cdot \mathrm{mL}^{-1^{\mathrm{a}}}\end{array}$ & $\begin{array}{c}0.25 \\
\mathrm{mg} \cdot \mathrm{mL}^{-1^{\mathrm{a}}}\end{array}$ & $\begin{array}{c}1 \\
\mathrm{mg} \cdot \mathrm{mL}^{-1^{\mathrm{a}}}\end{array}$ \\
\hline \multirow{4}{*}{ Lead } & Bir Nhass & 30 & 100 & 100 & 56.67 & - \\
\hline & Sidi Bouatman & 8 & 100 & 100 & 100 & - \\
\hline & Tenfit mine & 21 & 100 & 52.38 & 9.52 & - \\
\hline & Total & 59 & 100 & 84.13 & 55.40 & - \\
\hline \multirow{4}{*}{ Cadmium } & Bir Nhass & 30 & - & - & - & - \\
\hline & Sidi Bouatman & 8 & - & - & - & - \\
\hline & Tenfit mine & 21 & - & - & - & - \\
\hline & Total & 59 & - & - & - & - \\
\hline \multirow{4}{*}{ Copper } & Bir Nhass & 30 & 3.33 & - & - & - \\
\hline & Sidi Bouatman & 8 & 25.00 & - & - & - \\
\hline & Tenfit mine & 21 & 61.90 & - & - & - \\
\hline & Total & 59 & 30.08 & - & - & - \\
\hline \multirow{4}{*}{ Zinc } & Bir Nhass & 30 & 3.33 & - & - & - \\
\hline & Sidi Bouatman & 8 & 75 & - & - & - \\
\hline & Tenfit mine & 21 & 23.81 & - & - & - \\
\hline & Total & 59 & 34.05 & - & - & - \\
\hline \multirow{4}{*}{ Chromium } & Bir Nhass & 30 & 100 & - & - & - \\
\hline & Sidi Bouatman & 8 & 100 & - & - & - \\
\hline & Tenfit mine & 21 & 100 & - & - & - \\
\hline & Total & 59 & 100 & - & - & - \\
\hline
\end{tabular}

${ }^{a}$ Results are expressed in percentage of strains grown on culture medium with metal per total tested actinobacteria from each mining residue. $(-)$ : no tolerant strains.

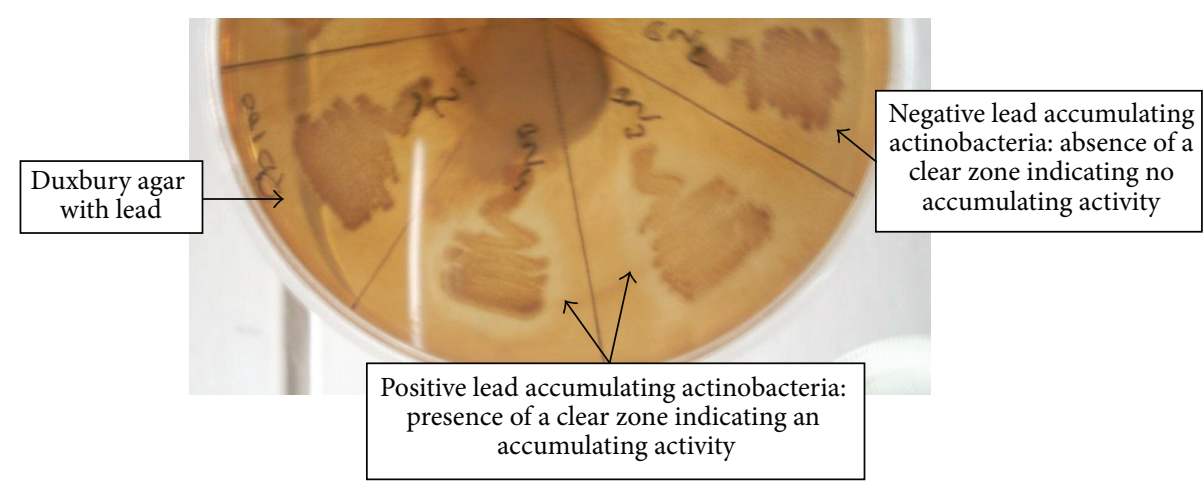

FIgURE 3: Example of positive and negative lead accumulating actinobacteria on Duxbury agar supplemented with $\mathrm{Pb}$.

KF479167, KF479168, KF479169, KF479170, KF479171, KF479172, KF479173, KF479174, KF479175, KF479176, KF479177, KF479178, KF479179, KF479180, KF479181, KF479182, KF479183, KF479184, KF479185, KF479186, KF479187, KF479188, KF479189, and KF479190, respectively, for Streptomyces strains BN2, BN3, BN4, BN7, BN9, BN12, BN13, BN17, BN22, BN23, BN24, BN25, BN48, BN68, BN69, BN71, BN72, BN73, BN82, GT1, GT2, GT6, GT15, GT39, SB22, SB30, and SB31.

3.5. Siderophore Analysis. For this parameter, 27 lead accumulating actinobacterial isolates were checked for siderophore secretion. Strains were cultivated on CAS medium for
7 days and, when a red or orange halo appeared around colonies, strain was considered as positive for the secretion of siderophore and was able to chelate iron from the culture medium (Figure 5). The universal siderophore assay was positive for only 12 of the 27 tested isolates (BN4, BN17, BN24, BN68, BN72, BN82, GT1, GT2, GT6, GT15, SB30, and SB31).

All the 12 siderophore positive strains were able to produce hydroxamate siderophore type, and none of them was able to produce catecholate siderophore.

\section{Discussion}

The aim of this study was to select actinobacteria strains from heavy metal contaminated sources of Moroccan abandoned 


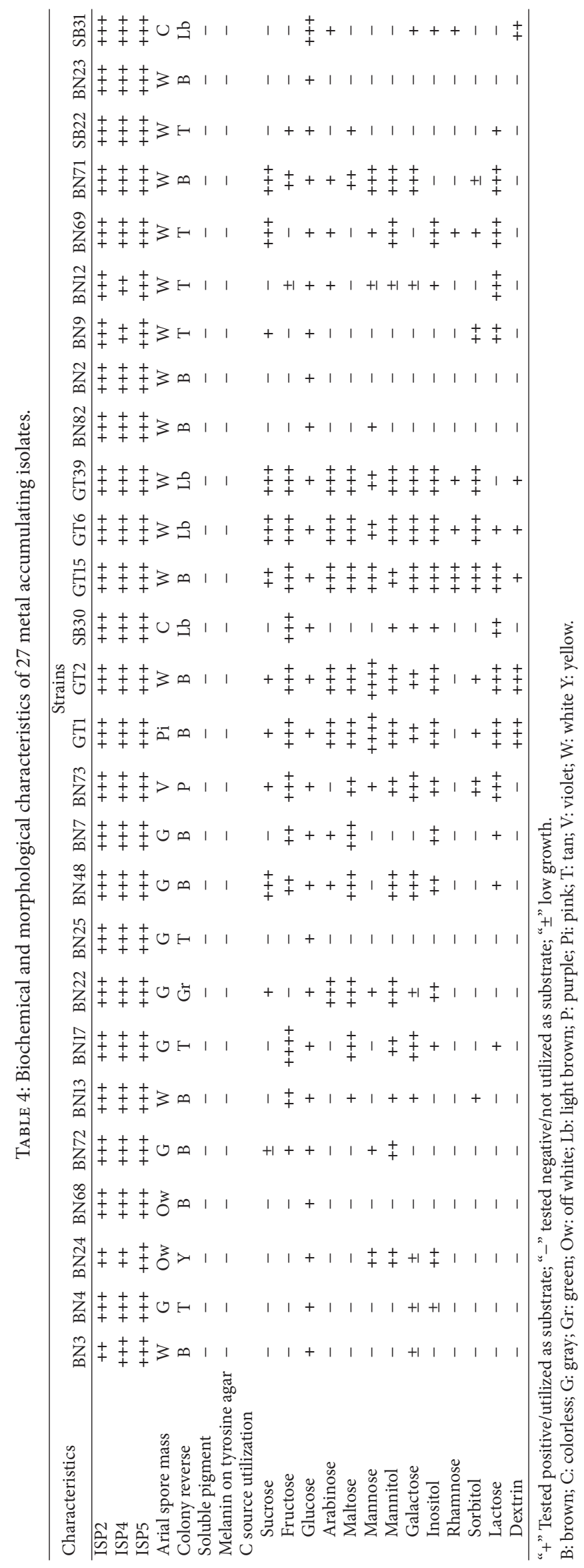


TABLE 5: Comparison of percent similarities between our 16S rRNA gene sequence and sequences present in the genomic database banks using NCBI BLAST.

\begin{tabular}{|c|c|c|c|}
\hline Strains & $\begin{array}{l}\text { Percentage of sequence } \\
\text { identities (\%) }\end{array}$ & Actinomycetes strains & $\begin{array}{c}\text { Accession } \\
\text { number }\end{array}$ \\
\hline $\begin{array}{l}\text { Streptomyces sp. BN2 } \\
\text { Streptomyces sp. BN9 } \\
\text { Streptomyces sp. BN12 } \\
\text { Streptomyces sp. BN23 } \\
\text { Streptomyces sp. BN71 } \\
\text { Streptomyces sp. SB22 }\end{array}$ & 99 & $\begin{array}{l}\text { Streptomyces sp. strain NT307(K3) } \\
\text { Streptomyces albus subsp. albus (NRRL B-2365) } \\
\text { Streptomyces flocculus (NBRC 13041) }\end{array}$ & $\begin{array}{l}\text { AJ002083.1 } \\
\text { DQ026669.1 } \\
\text { NR_041100.1 }\end{array}$ \\
\hline Streptomyces sp. BN7 & 99 & $\begin{array}{c}\text { Streptomyces sp. HB096 } \\
\text { Streptomyces diastaticus subsp. diastaticus (NBRC 3714) }\end{array}$ & $\begin{array}{l}\text { GU213492.1 } \\
\text { NR041209.1 }\end{array}$ \\
\hline $\begin{array}{l}\text { Streptomyces sp. BN13 } \\
\text { Streptomyces sp. BN17 }\end{array}$ & 99 & $\begin{array}{c}\text { Streptomyces gougerotii (NBRC 13043) } \\
\text { Streptomyces sp. HB096 }\end{array}$ & $\begin{array}{l}\text { NR112610.1 } \\
\text { GU213492.1 }\end{array}$ \\
\hline $\begin{array}{l}\text { Streptomyces sp. BN22 } \\
\text { Streptomyces sp. BN25 } \\
\text { Streptomyces sp. BN48 }\end{array}$ & 100 & $\begin{array}{c}\text { Streptomyces sp. HB096 } \\
\text { Streptomyces rutgersensis (NBRC 12819) }\end{array}$ & $\begin{array}{l}\text { GU213492.1 } \\
\text { NR041077.1 }\end{array}$ \\
\hline $\begin{array}{l}\text { Streptomyces sp. BN3 } \\
\text { Streptomyces sp. BN24 } \\
\text { Streptomyces sp. BN68 } \\
\end{array}$ & 100 & $\begin{array}{l}\text { Streptomyces sp. (VTT E-062974) } \\
\text { Streptomyces fungicidicus (YH04) } \\
\text { Streptomyces sp. L116 }\end{array}$ & $\begin{array}{l}\text { EU430546.1 } \\
\text { AY636155.1 } \\
\text { EU410509.1 }\end{array}$ \\
\hline Streptomyces sp. BN4 & 99 & $\begin{array}{c}\text { Streptomyces sp. (VTT E-062974) } \\
\text { Streptomyces sp. L116 }\end{array}$ & $\begin{array}{l}\text { EU430546.1 } \\
\text { EU410509.1 }\end{array}$ \\
\hline Streptomyces sp. BN69 & 99 & $\begin{array}{c}\text { Streptomyces albus subsp. albus (NRRL B-2365) } \\
\text { Streptomyces gibsonii (NBRC 15415) }\end{array}$ & $\begin{array}{r}\text { DQ026669.1 } \\
\text { NR041180.1 }\end{array}$ \\
\hline Streptomyces sp. BN72 & 99 & $\begin{array}{l}\text { Streptomyces sampsonii strain S151A } \\
\text { Streptomyces sp. VTT E-062974 }\end{array}$ & $\begin{array}{r}\text { HQ439905.1 } \\
\text { EU430546.1 }\end{array}$ \\
\hline Streptomyces sp. BN73 & 100 & $\begin{array}{l}\text { Streptomyces rochei strain A-1 } \\
\text { Streptomyces sp. (NEAU-L11) }\end{array}$ & $\begin{array}{r}\text { GQ392058.1 } \\
\text { JF502572.1 }\end{array}$ \\
\hline Streptomyces sp. BN82 & 99 & $\begin{array}{c}\text { Actinobacterium BH0951 } \\
\text { Streptomyces aurantiogriseus strain NRRL B-5416 }\end{array}$ & $\begin{array}{c}\text { GU265720.1 } \\
\text { AY999773 }\end{array}$ \\
\hline $\begin{array}{l}\text { Streptomyces sp. GT1 } \\
\text { Streptomyces sp. GT2 }\end{array}$ & 99 & $\begin{array}{c}\text { Streptomyces sp. CS38 } \\
\text { Streptomyces kanamyceticus (NRRL B-2535) } \\
\text { Streptomyces aureus (NBRC 100912) } \\
\text { Streptomyces kanamyceticus (NBRC 13414) }\end{array}$ & $\begin{array}{r}\text { EF494232.1 } \\
\text { NR043822.1 } \\
\text { NR112608.1 } \\
\text { NR112397.1 }\end{array}$ \\
\hline $\begin{array}{l}\text { Amycolatopsis sp. GT6 } \\
\text { Amycolatopsis sp. GT15 } \\
\text { Amycolatopsis sp. GT39 }\end{array}$ & 99 & $\begin{array}{c}\text { Amycolatopsis sp. SA08 } \\
\text { Amycolatopsis decaplanina (DSM 44594) } \\
\text { Amycolatopsis japonica (MG 417-CF 17) } \\
\text { Amycolatopsis keratiniphila subsp. nogabecina (DSM 44586) } \\
\text { Amycolatopsis orientalis (IMSNU 20057) }\end{array}$ & $\begin{array}{l}\text { GU294685.1 } \\
\text { NR025562.1 } \\
\text { NR025561.1 } \\
\text { NR025562.1 } \\
\text { NR042040.1 }\end{array}$ \\
\hline $\begin{array}{l}\text { Streptomyces sp. SB30 } \\
\text { Streptomyces sp. SB31 }\end{array}$ & 99 & $\begin{array}{l}\text { Streptomyces pluricolorescens (NAPOLSKAYA1, isolate 2) } \\
\text { Streptomyces parvus (13647J) } \\
\text { Streptomyces praecox (CGMCC } 4.1782 \text { clone } 2)\end{array}$ & $\begin{array}{l}\text { FR837631.1 } \\
\text { EU741140.1 } \\
\text { JQ924403.1 } \\
\end{array}$ \\
\hline
\end{tabular}

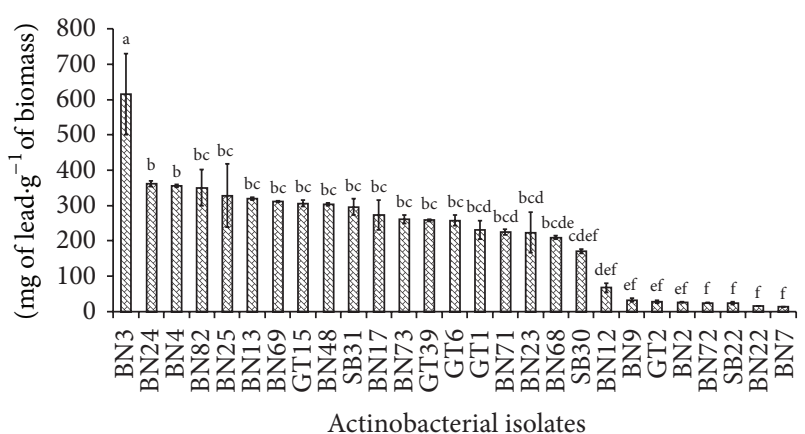

Figure 4: Quantities of removed lead by the tested actinobacteria strains. mines. Heavy metal resistance and accumulation capacities of selected strains were performed in order to investigate their applicability as a bioremediators for polluted areas.

Physicochemical analysis of mining residue samples revealed the presence of high concentrations of heavy metals in all studied sites especially for $\mathrm{Pb}, \mathrm{Cu}$, and $\mathrm{Zn}$. In general, these results were in accordance with previous studies carried out in abandoned mines in Morocco [21] and in others countries such as Sweden, Canada, and Spain [37-40]. Excepting Kettara residues samples, all samples presented a neutral to slightly alkaline $\mathrm{pH}$ explained by the presence of high concentration of carbonates. Furthermore, the reason behind acidic $\mathrm{pH}$ in Kettara mine is related to the oxidation of sulfuric acid which, in the absence of sufficient neutralizing 


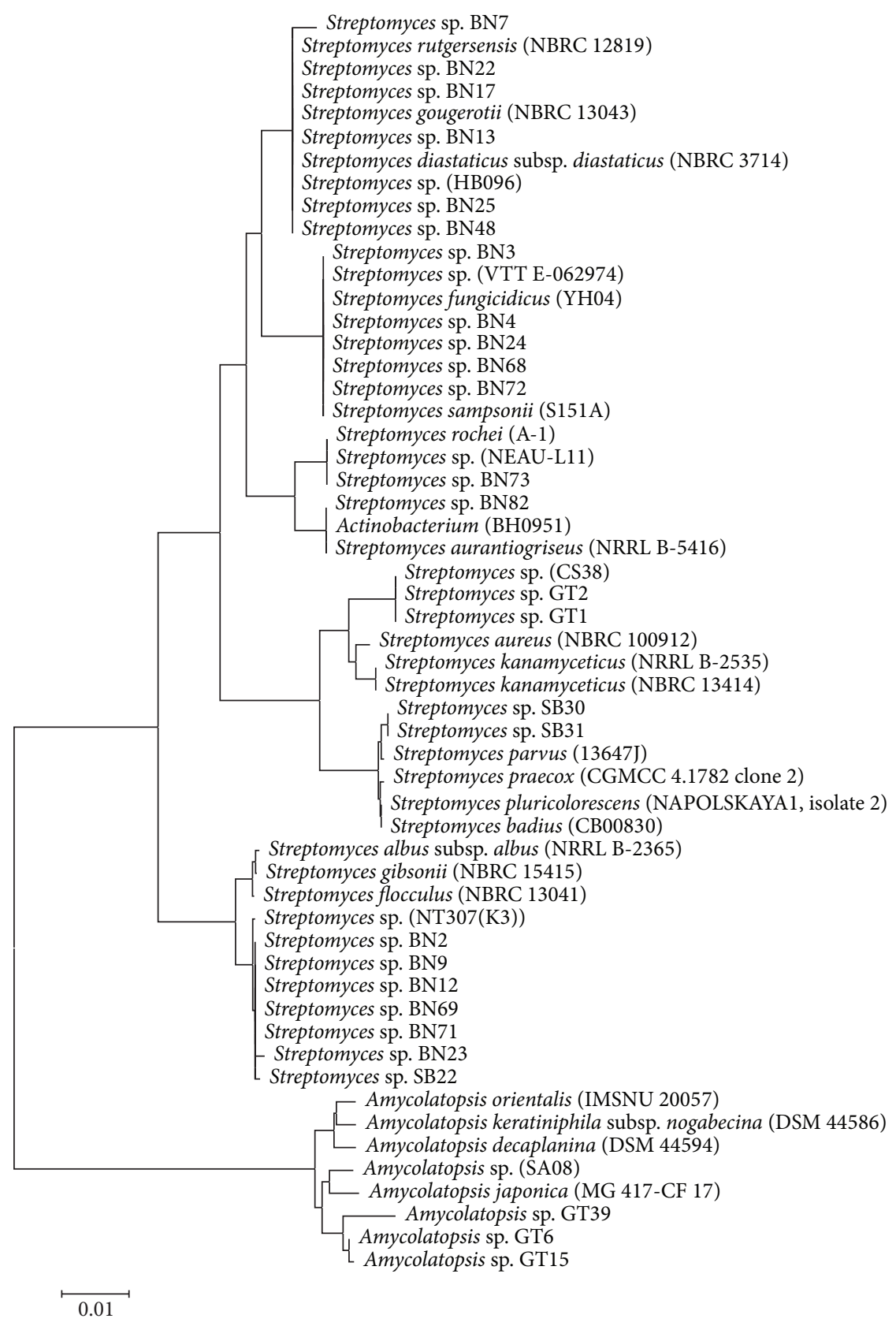

FIGURE 5: Evolutionary relationships of taxa: the evolutionary history was inferred using the neighbor-joining method [71]. The optimal tree with the sum of branch length $=0.21501137$ is shown. The tree is drawn to scale, with branch lengths in the same units as those of the evolutionary distances used to infer the phylogenetic tree. The evolutionary distances were computed using the maximum composite likelihood method [72] and are in the units of the number of base substitutions per site. The analysis involved 55 nucleotide sequences. Codon positions included were $1 \mathrm{st}+2 \mathrm{nd}+3 \mathrm{rd}+$ noncoding. All positions containing gaps and missing data were eliminated. There were a total of 1392 positions in the final dataset. Evolutionary analyses were conducted in MEGA5 [32]. The scale bar represents 0.01 substitutions per nucleotide position.

components, brought down the $\mathrm{pH}$ [41-43]. These proprieties may affect directly living bacteria's diversity and ecophysiology in the prospected sites. In the present study, the acidic $\mathrm{pH}$ may explain why we did not isolate any actinobacteria strain from the Kettara site. Moreover, our results showed a negative correlation between actinobacterial diversity and heavy metal pollution levels. Indeed, we have isolated more actinobacterial strains in BN (30 isolates) and GT (21 isolates) than in SB site (08 isolates). Several authors pointed out that heavy metal pollution of aquatic and soil ecosystems induce a decrease in the microbial diversity $[5,9]$. Haferburg and Kothe [4] reported that there was a clear mutual influence in mining areas: not only are microbes in soil affected by their environment directly and indirectly but also they control 


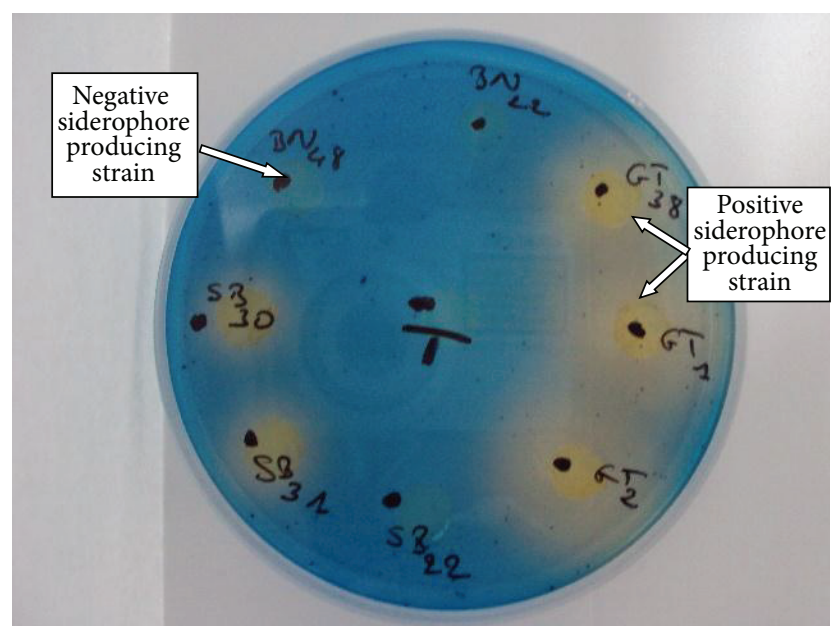

T: Control

FIGURE 6: Screening of siderophore producing actinobacteria using chrome azurol $\mathrm{S}$ agar (positive strain are yellow-orange, negative strain are blue).

particular soil parameters. These authors suggested also that growth and metabolism can lead to changes in $\mathrm{pH}$, redox potential, and ionic strength of the soil.

From the prospected mining sites, we have isolated a total of 59 actinobacteria strains. All isolates were screened for their resistance to $\mathrm{Pb}, \mathrm{Zn}, \mathrm{Cd}, \mathrm{Cu}$, and $\mathrm{Cr}$. In order to assess the applicability and the suitability of culture medium in screening heavy metal resistant bacteria, we have used two culture media (rich medium, nutrient agar and minimum medium, Duxbury agar).

Obtained data revealed that all isolates streaked on nutrient agar with metals did not show any significant difference in growth comparing to the control one. In contrast, a significant difference in growth was observed for strains tested on Duxbury agar with metals in comparison with the control. We suggest that this is not only due to the metal kind but also due to the culture medium composition. Indeed, the medium composition may modulate the metal availability and consequently its toxicity. Nutrient agar containing organic compounds can chelate metals and make it not available for the tested microorganisms [16, 44]. In contrast, when isolates were streaked on Duxbury agar with metals, only some of them showed resistance ability. So, the latter medium may be considered as a more suitable support for such studies. Our findings agree with other reports in which frequently minimal medium has been used. Indeed, complex media are inadequate due to the high concentration of organic components that absorb metallic ions. Moreover, some heavy metals have high affinity to bind organic matter implying a decrease of their bioavailability $[16,44]$. The same observations were reported by Majzlik et al. [45]. Schmidt et al. [46] reported that a Streptomyces strain grew very differently depending on growth media (minimal medium and TSB complex medium) amended with nickel.

Various methods of actinobacteria classification are used elsewhere [47]. In several works, the combination of
TABLE 6: Heavy metal concentrations $\left(\mathrm{mg} \cdot \mathrm{mL}^{-1}\right)$ available in mining residues [21].

\begin{tabular}{lccc}
\hline & Goundafa & Sidi Bouatman & Bir Nhass \\
\hline $\mathrm{Zn}$ & 3.600 & 8.406 & 7.671 \\
$\mathrm{~Pb}$ & 1.280 & 1.922 & 0.065 \\
$\mathrm{Cu}$ & 0.022 & 0.023 & 0.110 \\
$\mathrm{Cd}$ & 0.043 & 0.174 & 0.054 \\
\hline
\end{tabular}

morphological and chemical properties with $16 \mathrm{~S}$ rRNA sequencing has been used to differentiate between actinobacteria genera [48]. The $16 \mathrm{~S}$ rRNA gene sequencing of our selected isolates demonstrated that $88.9 \%$ of these organisms are phylogenetically related to members of the Streptomyces genus, and $11.1 \%$ are closely related to members of the Amycolatopsis genus. Although, the neighbor-joining method showed that some isolates belong to the same species, they have different physiological and biochemical features. Further analyses (as DNA-DNA hybridization) are required to clarify the systematic belonging of some of our selected strains.

It is generally assumed that environmental heavy metal pollution leads to the establishment of a tolerant or resistant microbial population [49]. In the present study, some of the tested strains could resist relatively high concentrations of lead (up to $0.55 \mathrm{mg} \cdot \mathrm{mL}^{-1}$ for Streptomyces sp. BN2) and hexavalent chromium (up to $0.10 \mathrm{mg} \cdot \mathrm{mL}^{-1}$ ). Polti et al. [16] have previously isolated nine chromium resistant actinobacteria strains from contaminated sites in Tucumán (Argentina), which were identified as members of the genus Streptomyces. Resistance of actinobacteria to $\mathrm{Pb}$ was previously reported by Sanjenbam et al. [50] who have described a maximum tolerance concentration of Streptomyces that reaches $1.8 \mathrm{mg} \cdot \mathrm{mL}^{-1}$.

Our isolates could also resist $\mathrm{Cu}$ and $\mathrm{Zn}\left(0.10 \mathrm{mg} \cdot \mathrm{mL}^{-1}\right)$ and corroborate those of Albarracín et al. [51] who showed that Amycolatopsis tucumanensis strains, isolated from copper-polluted sediments, were resistant to concentrations up to $0.08 \mathrm{mg} \cdot \mathrm{mL}^{-1}$ of $\mathrm{CuSO}_{4}$. In the other hand, none of our isolates were able to grow in the presence of Cadmium. A similar observations were recorded for Streptomyces coelicolor A3(2) isolated from an abandoned uranium mining area [46]. Amycolatopsis sp. GT6, Amycolatopsis sp. GT15, and Amycolatopsis sp. GT39 can tolerate very high concentrations of the four metals tested $(\mathrm{Pb}, 0.25 ; \mathrm{Cu}, 0.10$; $\mathrm{Cr}, 0.15$; and $\left.\mathrm{Zn}, 0.10 \mathrm{mg} \cdot \mathrm{mL}^{-1}\right)$. From obtained results, it appeared that actinobacterial MICs values which are determined with traditional media did not agree with metal concentrations detected in sites. Selected strains are unable to resist to heavy metal's concentrations equal to those recorded in mining residue samples. This may be explained by the presence of nonavailable forms of metals in sites with high percentages. In a previous study on the same sites (Sidi Bouatman, Bir Nhass, and Goundafa) heavy metals ( $\mathrm{Pb}$, $\mathrm{Cu}, \mathrm{Cd}$ and $\mathrm{Zn}$ ) are generally unavailable (Table 6) [21]. Moreover, some interactions can alter chemical speciation and the bioavailability of these micropollutants. In the same way, some authors have pointed out that the soluble and 
exchangeable fractions of heavy metals largely determine the availability and mobility of heavy metals [52, 53]. Furthermore, $\mathrm{pH}$ is one of the most decisive factors who act on the solubility of heavy metals. In addition, the presence of limestone in Goundafa and Sidi Bouatman residues may explain the low availability of their toxic form of heavy metals. According to these observations we can conclude that our selected isolates had abilities to tolerate relative high metal concentrations than what is available in sampling sites. This may also explain why all isolates were sensitive to cadmium.

Metal accumulation or biotransformation is alternative mechanisms for metal detoxification used by bacteria [54]. Chemical precipitation taste of heavy metals using hydrogen sulfide technic $\left(\mathrm{H}_{2} \mathrm{~S}\right)$ revealed that only 27 isolates have a strong ability to accumulate $\mathrm{Pb}$; the accumulated concentrations recorded high levels (up to $600 \mathrm{mg}$ of $\mathrm{Pb}$ per $\mathrm{g}$ of biomass for Streptomyces sp. BN3). As it had been already pointed out by Hernández et al. [27], the technic used to detect heavy metal accumulator actinobacterial strains did give satisfactory results. Obtained results show that selected isolates are able to accumulate only lead metal. Similarly, Rho and Kim [55] reported the capacity of Streptomyces viridochromogenes to accumulate lead up to $164 \mu \mathrm{g} \cdot \mathrm{mg}^{-1}$. Significantly, lead adsorption was much higher for various fungi including Mucor rouxii (769 $\mathrm{mg}^{-1} \mathrm{~g}^{-1}$ [56] and Paecilomyces marquandii (324 mg. $\mathrm{g}^{-1}$ ) [57]. Streptomyces albus was also able to adsorb copper and gold as well as lead in its cell wall [58]. In contrast, A. tucumanensis showed the highest bioaccumulation value for growing cells $\left(25 \mathrm{mg} \cdot \mathrm{g}^{-1}\right)$ among other microorganisms previously proposed for bioremediation processes [51]. S. zinciresistens accumulated $\mathrm{Zn}^{2+}$ $\left(26.81 \mathrm{mg} \cdot \mathrm{g}^{-1}\right)$ and $\mathrm{Cd}^{2+}\left(85 \mathrm{mg} \cdot \mathrm{g}^{-1}\right)$ mainly on the cell wall followed by intracellular accumulation [59]. The surface envelopes of bacterial cells can adsorb various heavy metals by means of ionic bonds to their intrinsic chemical groups [55]. Anionic groups such as carboxylate and phosphate groups of peptidoglycan and teichoic acids are considered as the major metal binding sites [55].

The secondary metabolites produced by actinobacteria may enable the bacteria to cope with stress factors including toxic levels of heavy metals [14]. Another study reveals that a Streptomyces strain, producing a siderophore, was capable of sequestering a range of ions including $\mathrm{Mn}$, Co, $\mathrm{Cd}, \mathrm{Ni}, \mathrm{Al}, \mathrm{Li}, \mathrm{Cu}, \mathrm{Zn}$, and $\mathrm{Mg}$ [60]. In the present study, among $27 \mathrm{~Pb}$ resistant and accumulating strains, only 12 were found to be able to produce siderophore from hydroxamate family. These findings suggest that there is no relationship between metal accumulation capacities and production of siderophore especially in iron rich environs. The exploitation of these isolates in bioremediation of metal contaminated iron deficient soils may be useful tool. In the same way, some authors suggested application of these kinds of bacteria as an interface with plants able to accumulate metals $[61,62]$.

In the other hand, we have recorded that Streptomyces sp. $\mathrm{BN} 2$ strain shows a high resistance level to $\mathrm{Pb}\left(0.55 \mathrm{mg} \cdot \mathrm{mL}^{-1}\right)$ and a low accumulation capacity of this metal $\left(26.37 \mathrm{mg} \cdot \mathrm{g}^{-1}\right)$. Streptomyces sp. BN3 strain, which is twofold less resistant to
$\mathrm{Pb}$ than Streptomyces sp. BN2 strain, was able to accumulate more than 26 times the quantity of $\mathrm{Pb}$ than Streptomyces sp. BN2. Streptomyces sp. BN48 strain showed a low resistance level $\left(0.20 \mathrm{mg} \cdot \mathrm{mL}^{-1}\right)$ and presented an intermediate accumulation capacity $\left(282.74 \mathrm{mg} \cdot \mathrm{g}^{-1}\right)$ in comparison with Streptomyces sp. BN3 and Streptomyces sp. BN2. Consequently, it can be clearly noticed that there was no correlation between resistance level and accumulation capacity for tested strains.

In fact, pollution levels may influence the genetic makeup of resident microorganisms. Members of Streptomyces and Amycolatopsis genera can survive in polluted environments with heavy metals as mentioned by Polti et al. [16] and Albarracín et al. [17]. Álvarez et al. [63] reported that the presence of heavy metal resistant strains in different Streptomyces clades may have two different explanations: (i) the resistance was already present in the most recent common ancestor (MRCA) and was then inherited by the different lineages; (ii) the different lineages inherited from the MRCA the capacity to develop new mechanisms or modify existing ones, in order to generate resistance to heavy metals. Schütze and Kothe [64] indicated that several morphological, physiological, and reproductive characteristics of Streptomyces (the filamentous growth, the formation of hyphae, and the production of spores) would allow its species to occupy extreme environments. Since these properties are shared by all species of the genus, this can be interpreted as evidence that supports the inheritance of resistance to heavy metals from the MRCA; and this is in agreement with the work done by Zhou et al. [65].

Many processes could be used in the bioremediation of contaminated wastewaters and soils. Microorganisms as actinobacteria might be a good tool which can be used in a bioreactor configuration to treat metal contaminated wastes prior to discharge into the environment. Recently, reports pointed out that such microorganisms could be used in large-scale biofilm bioreactors for the treatment of metalladen wastewater [66-70]. In the present study, living cells of actinobacteria gave satisfactory metal accumulating results especially for lead. More studies should be designed at molecular levels to evaluate and to identify mechanisms involved in the association between metal resistances and accumulation in order to upgrade the bioremediation potential of theses strains. These studies seem to be highly promising in terms of the creation of fields that encourage the development of bioremediation processes using native microorganisms.

\section{Conclusion}

Mining sites are considered suitable for the isolation of heavy metal resistant microorganisms and useful sources of potential bioremediators. Many abandoned mining sites are highly contaminated with metallic elements. It is very interesting to restore them especially by combining several environment friendly remediation techniques and by improving their quality. In our opinion, some of our selected actinobacteria can play very significant roles in the remediation of contaminated sites. However, further studies are required to enhance bioremediation potentialities of our strains to 
perform biological process and to optimize their role in removing heavy metals from contaminated environments.

\section{Conflict of Interests}

The authors declare that there is no conflict of interests regarding the publication of this paper.

\section{References}

[1] E. Valdman, L. Erijman, F. L. P. Pessoa, and S. G. F. Leite, "Continuous biosorption of $\mathrm{Cu}$ and $\mathrm{Zn}$ by immobilized waste biomass Sargassum sp," Process Biochemistry, vol. 36, no. 8-9, pp. 869-873, 2001.

[2] I. H. Çeribasi and U. Yetis, "Biosorption of $\mathrm{Ni}(\mathrm{ii})$ and $\mathrm{Pb}$ (ii) by Phanerochaete chrysosporium from a binary metal systemkinetics," Water SA, vol. 27, no. 1, pp. 15-20, 2001.

[3] S. Zafar, F. Aqil, and I. Ahmad, "Metal tolerance and biosorption potential of filamentous fungi isolated from metal contaminated agricultural soil," Bioresource Technology, vol. 98, no. 13, pp. 2557-2561, 2007.

[4] G. Haferburg and E. Kothe, "Microbes and metals: interactions in the environment," Journal of Basic Microbiology, vol. 47, no. 6, pp. 453-467, 2007.

[5] L. Ezzouhri, E. Castro, M. Moya, F. Espinola, and K. Lairini, "Heavy metal tolerance of filamentous fungi isolated from polluted sites in Tangier, Morocco," African Journal of Microbiology Research, vol. 3, no. 2, pp. 35-48, 2009.

[6] M. R. Bruins, S. Kapil, and F. W. Oehme, "Microbial resistance to metals in the environment," Ecotoxicology and Environmental Safety, vol. 45, no. 3, pp. 198-207, 2000.

[7] J. Selvin, S. Shanmugha Priya, G. Seghal Kiran, T. Thangavelu, and N. Sapna Bai, "Sponge-associated marine bacteria as indicators of heavy metal pollution," Microbiological Research, vol. 164, no. 3, pp. 352-363, 2009.

[8] S. Zapotoczny, A. Jurkiewicz, G. Tylko, T. Anielska, and K. Turnau, "Accumulation of copper by Acremonium pinkertoniae, a fungus isolated from industrial wastes," Microbiological Research, vol. 162, no. 3, pp. 219-228, 2007.

[9] V. N. Kavamura and E. Esposito, "Biotechnological strategies applied to the decontamination of soils polluted with heavy metals," Biotechnology Advances, vol. 28, no. 1, pp. 61-69, 2010.

[10] J. Solecka, J. Zajko, M. Postek, and A. Rajnisz, "Biologically active secondary metabolites from Actinomycetes," Central European Journal of Biology, vol. 7, no. 3, pp. 373-390, 2012.

[11] M. S. Louis, J. M. Benito, V. H. Albarracín, T. Lebeau, M. J. Amoroso, and C. M. Abate, "Heavy-metal resistant actinomycetes," in Heavy-Metal Resistant Actinomycetes, E. Lichtfouse, J. Schwarzbauer, and D. Robert, Eds., pp. 757-767, Springer, Berlin, Germany, 2005.

[12] J. Bérdy, "Bioactive microbial metabolites," The Journal of Antibiotics, vol. 58, no. 1, pp. 1-26, 2005.

[13] A. Schmidt, G. Haferburg, M. Sineriz, D. Merten, G. Büchel, and E. Kothe, "Heavy metal resistance mechanisms in actinobacteria for survival in AMD contaminated soils," Chemie der ErdeGeochemistry, vol. 65, Supplement 1, pp. 131-144, 2005.

[14] N.-W. So, J.-Y. Rho, S.-Y. Lee, I. C. Hancock, and J.-H. Kim, "A lead-absorbing protein with superoxide dismutase activity from Streptomyces subrutilus," FEMS Microbiology Letters, vol. 194, no. 1, pp. 93-98, 2001.
[15] V. L. Colin, L. B. Villegas, and C. M. Abate, "Indigenous microorganisms as potential bioremediators for environments contaminated with heavy metals," International Biodeterioration \& Biodegradation, vol. 69, pp. 28-37, 2012.

[16] M. A. Polti, M. J. Amoroso, and C. M. Abate, "Chromium(VI) resistance and removal by actinomycete strains isolated from sediments," Chemosphere, vol. 67, no. 4, pp. 660-667, 2007.

[17] V. H. Albarracín, P. Alonso-Vega, M. E. Trujillo, M. J. Amoroso, and C. M. Abate, "Amycolatopsis tucumanensis sp. nov., a copper-resistant actinobacterium isolated from polluted sediments," International Journal of Systematic and Evolutionary Microbiology, vol. 60, part 2, pp. 397-401, 2010.

[18] V. H. Albarracín, B. Winik, E. Kothe, M. J. Amoroso, and C. M. Abate, "Copper bioaccumulation by the actinobacterium Amycolatopsis sp. AB0," Journal of Basic Microbiology, vol. 48, no. 5, pp. 323-330, 2008.

[19] J. S. D. Costa, V. H. Albarracín, and C. M. Abate, "Responses of environmental Amycolatopsis strains to copper stress," Ecotoxicology and Environmental Safety, vol. 74, no. 7, pp. 2020-2028, 2011.

[20] M. S. Fuentes, C. S. Benimeli, S. A. Cuozzo, and M. J. Amoroso, "Isolation of pesticide-degrading actinomycetes from a contaminated site: bacterial growth, removal and dechlorination of organochlorine pesticides," International Biodeterioration and Biodegradation, vol. 64, no. 6, pp. 434-441, 2010.

[21] A. EL Gharmali, Impact des résidus miniers et des eaux résiduaires sur la contamination métallique des écosystèmes aquatiques et terrestres de la région de Marrakech, Maroc [Ph.D. thesis], University Cadi Ayyad, Marrakech, Morocco, 2005.

[22] M. Hakkou, M. Pétrissans, I. El Bakali, P. Gérardin, and A. Zoulalian, "Wettability changes and mass loss during heat treatment of wood," Holzforschung, vol. 59, no. 1, pp. 35-37, 2005.

[23] AFNOR, Quality of Soil. Soils, Sediments, Mise en Solution Totale par Attaque Acide, AFNOR, Paris, France, 1996.

[24] G. Aubert, Methods of Soil Analysis, G.R.D.P., Marseille, France, 1978.

[25] K. L. Jones, "Fresh isolates of actinomycetes in which the presence of sporogenous," Journal of Bacteriology, vol. 57, no. 2, pp. 141-145, 1949.

[26] T. Duxbury, “Toxicity of heavy metals to soil bacteria," FEMS Microbiology Letters, vol. 11, no. 2-3, pp. 217-220, 1981.

[27] A. Hernández, R. P. Mellado, and J. L. Martínez, "Metal accumulation and vanadium-induced multidrug resistance by environmental isolates of Escherichia hermannii and Enterobacter cloacae," Applied and Environmental Microbiology, vol. 64, no. 11, pp. 4317-4320, 1998.

[28] E. B. Shirling and D. Gottlieb, "Methods for characterization of streptomyces species," International Journal of Systematic Bacteriology, vol. 16, no. 3, pp. 313-340, 1966.

[29] H. Prauser, "Aptness and application of colour codes for exact description of colours of Streptomycetes," Zeitschrift für Allgemeine Mikrobiologie, vol. 4, no. 1, pp. 95-98, 1964.

[30] D. A. Hopwood, M. J. Bibb, K. F. Chater et al., Genetic Manipulation of Streptomyces. A Laboratory Manual, The John Innes Institute, Norwich, UK, 1985.

[31] D. J. Lane, "16S/23S rRNA sequencing," in Nucleic Acid Techniques in Bacterial Systematics, E. Stackebrandt and M. Goodfellow, Eds., pp. 115-175, John Wiley \& Sons, New York, NY, USA, 1991.

[32] K. Tamura, D. Peterson, N. Peterson, G. Stecher, M. Nei, and S. Kumar, "MEGA5: molecular evolutionary genetics analysis 
using maximum likelihood, evolutionary distance, and maximum parsimony methods," Molecular Biology and Evolution, vol. 28, no. 10, pp. 2731-2739, 2011.

[33] B. Schwyn and J. B. Neilands, "Universal chemical assay for the detection and determination of siderophores," Analytical Biochemistry, vol. 160, no. 1, pp. 47-56, 1987.

[34] T. Z. Csaky, "On the estimation of bound hydroxylamine in biological materials," Acta Chemica Scandinavica, vol. 2, pp. 450-454, 1948.

[35] L. E. Arnow, "Colorimetric determination of the components of 3, 4-dihydroxyphenylalanine-tyrosine mixtures," The Journal of Biological Chemistry, vol. 118, pp. 531-537, 1937.

[36] J. B. Neilands and K. Nakamura, "Detection, determination, isolation, characterization and regulation of microbial iron chelates," in CRC Handbook of Microbial Iron Chelates, G. Winkelmann, Ed., pp. 1-14, CRC Press, Boca Raton, Fla, USA, 1991.

[37] H. Holmström, J. Ljungberg, and B. Öhlander, “The character of the suspended and dissolved phases in the water cover of the flooded mine tailings at Stekenjokk, Northern Sweden," Science of the Total Environment, vol. 247, no. 1, pp. 15-31, 2000.

[38] H. Holmström and B. Öhlander, "Layers rich in Fe- and Mnoxyhydroxides formed at the tailings-pond water interface, a possible trap for trace metals in flooded mine tailings," Journal of Geochemical Exploration, vol. 74, no. 1-3, pp. 189-203, 2001.

[39] J. Ljungberg and B. Öhlander, "The geochemical dynamics of oxidising mine tailings at Laver, Northern Sweden," Journal of Geochemical Exploration, vol. 74, no. 1-3, pp. 57-72, 2001.

[40] B. Vigneault, P. G. C. Campbell, A. Tessier, and R. de Vitre, "Geochemical changes in sulfidic mine tailings stored under a shallow water cover," Water Research, vol. 35, no. 4, pp. 10661076, 2001.

[41] S. R. Jennings, D. J. Dollhopf, and W. P. Inskeep, "Acid production from sulfide minerals using hydrogen peroxide weathering," Applied Geochemistry, vol. 15, no. 2, pp. 235-243, 2000.

[42] A. Khalil, L. Hanich, R. Hakkou, and M. Lepage, "GIS-based environmental database for assessing the mine pollution: a case study of an abandoned mine site in Morocco," Journal of Geochemical Exploration, vol. 144, part C, pp. 468-477, 2014.

[43] M. Lghoul, A. Maqsoud, R. Hakkou, and A. Kchikach, "Hydrogeochemical behavior around the abandoned Kettara mine site, Morocco," Journal of Geochemical Exploration, vol. 144, part C, pp. 456-467, 2013.

[44] R. S. Laxman and S. More, "Reduction of hexavalent chromium by Streptomyces griseus," Minerals Engineering, vol. 15, no. 11, pp. 831-837, 2002.

[45] P. Majzlik, A. Strasky, V. Adam et al., "Influence of zinc(II) and copper(II) ions on Streptomyces bacteria revealed by electrochemistry," International Journal of Electrochemical Science, vol. 6, no. 6, pp. 2171-2191, 2011.

[46] A. Schmidt, G. Haferburg, U. Lischke et al., "Heavy metal resistance to the extreme: streptomyces strains from a former uranium mining area," Chemie der Erde-Geochemistry, vol. 69, supplement 2, pp. 35-44, 2009.

[47] J. G. Holt, N. R. Krieg, P. H. A. Sneath, J. T. Staley, and S. T. Williams, Bergey's Manual of Determinative Bacteriology, Williams \& Williams, Baltimore, Md, USA, 9th edition, 1994.

[48] E. Stackebrandt, F. A. Rainey, and N. L. Ward-Rainey, "Proposal for a new hierarchic classification system, Actinobacteria classis nov," International Journal of Systematic Bacteriology, vol. 47, no. 2, pp. 479-491, 1997.
[49] A. Aleem, J. Isar, and A. Malik, "Impact of long-term application of industrial wastewater on the emergence of resistance traits in Azotobacter chroococcum isolated from rhizospheric soil," Bioresource Technology, vol. 86, no. 1, pp. 7-13, 2003.

[50] P. Sanjenbam, K. Saurav, and K. Kannabiran, "Biosorption of mercury and lead by aqueous Streptomyces VITSVK9 sp. isolated from marine sediments from the bay of Bengal, India," Frontiers of Chemical Science and Engineering, vol. 6, no. 2, pp. 198-202, 2012.

[51] V. H. Albarracín, M. J. Amoroso, and C. M. Abate, "Isolation and characterization of indigenous copper-resistant actinomycete strains," Chemie der Erde-Geochemistry, vol. 65, Supplement 1, pp. 145-156, 2005.

[52] Y. Ge, P. Murray, and W. H. Hendershot, "Trace metal speciation and bioavailability in urban soils," Environmental Pollution, vol. 107, no. 1, pp. 137-144, 2000.

[53] C. E. Martínez and H. L. Motto, "Solubility of lead, zinc and copper added to mineral soils," Environmental Pollution, vol. 107, no. 1, pp. 153-158, 2000.

[54] G. M. Gadd, "Metals and microorganisms: a problem of definition," FEMS Microbiology Letters, vol. 100, no. 1-3, pp. 197-203, 1992.

[55] J. Y. Rho and J. H. Kim, "Heavy metal biosorption and its significance to metal tolerance of streptomycetes," The Journal of Microbiology, vol. 40, no. 1, pp. 51-54, 2002.

[56] W. Lo, H. Chua, K.-H. Lam, and S.-P. Bi, "A comparative investigation on the biosorption of lead by filamentous fungal biomass," Chemosphere, vol. 39, no. 15, pp. 2723-2736, 1999.

[57] M. Słaba and J. Długoński, "Zinc and lead uptake by mycelium and regenerating protoplasts of Verticillium marquandii," World Journal of Microbiology and Biotechnology, vol. 20, no. 3, pp. 323-328, 2004

[58] B. Mattuschka, G. Straube, and J. T. Trevors, "Silver, copper, lead and zinc accumulation by Pseudomonas stutzeri AG259 and Streptomyces albus: electron microscopy and energy dispersive X-ray studies," BioMetals, vol. 7, no. 2, pp. 201-208, 1994.

[59] Y. Lin, X. Wang, B. Wang, O. Mohamad, and G. Wei, "Bioaccumulation characterization of zinc and cadmium by Streptomyces zinciresistens, a novel actinomycete," Ecotoxicology and Environmental Safety, vol. 77, pp. 7-17, 2012.

[60] I. Nakouti and G. Hobbs, "A new approach to studying ion uptake by actinomycetes," Journal of Basic Microbiology, vol. 53, no. 11, pp. 913-916, 2013.

[61] W. Wang, Z. Qiu, H. Tan, and L. Cao, "Siderophore production by actinobacteria," BioMetals, vol. 27, no. 4, pp. 623-631, 2014.

[62] T. Gaonkar and S. Bhosle, "Effect of metals on a siderophore producing bacterial isolate and its implications on microbial assisted bioremediation of metal contaminated soils," Chemosphere, vol. 93, no. 9, pp. 1835-1843, 2013.

[63] A. Álvarez, S. A. Catalano, and M. J. Amoroso, "Heavy metal resistant strains are widespread along Streptomyces phylogeny," Molecular Phylogenetics and Evolution, vol. 66, no. 3, pp. 10831088, 2013.

[64] E. Schütze and E. Kothe, "Bio-geo interactions in metalcontaminated soils," in Soil Biology, E. Kothe and A. Varma, Eds., vol. 31, pp. 163-182, Springer, Berlin, Germany, 2012.

[65] M. Zhou, X. Jing, P. Xie et al., "Sequential deletion of all the polyketide synthase and nonribosomal peptide synthetase biosynthetic gene clusters and a $900-\mathrm{kb}$ subtelomeric sequence of the linear chromosome of Streptomyces coelicolor," FEMS Microbiology Letters, vol. 333, no. 2, pp. 169-179, 2012. 
[66] L. Diels, P. H. Spaans, S. van Roy et al., "Heavy metals removal by sand filters inoculated with metal sorbing and precipitating bacteria," Hydrometallurgy, vol. 71, no. 1-2, pp. 235-241, 2003.

[67] A. Ganguli and A. K. Tripathi, "Bioremediation of toxic chromium from electroplating effluent by chromate-reducing Pseudomonas aeruginosa A2Chr in two bioreactors," Applied Microbiology and Biotechnology, vol. 58, no. 3, pp. 416-420, 2002.

[68] A. Malik, "Metal bioremediation through growing cells," Environment International, vol. 30, no. 2, pp. 261-278, 2004.

[69] W.-L. Smith, "Hexavalent chromium reduction and precipitation by sulphate-reducing bacterial biofilms," Environmental Geochemistry and Health, vol. 23, no. 3, pp. 297-300, 2001.

[70] A. S. Y. Ting and C. C. Choong, "Bioaccumulation and biosorption efficacy of Trichoderma isolate SP2F1 in removing copper (Cu(II)) from aqueous solutions," World Journal of Microbiology and Biotechnology, vol. 25, no. 8, pp. 1431-1437, 2009.

[71] N. Saitou and M. Nei, "The neighbor-joining method: a new method for reconstructing phylogenetic trees," Molecular Biology and Evolution, vol. 4, no. 4, pp. 406-425, 1987.

[72] K. Tamura, M. Nei, and S. Kumar, "Prospects for inferring very large phylogenies by using the neighbor-joining method," Proceedings of the National Academy of Sciences of the United States of America, vol. 101, no. 30, pp. 11030-11035, 2004. 

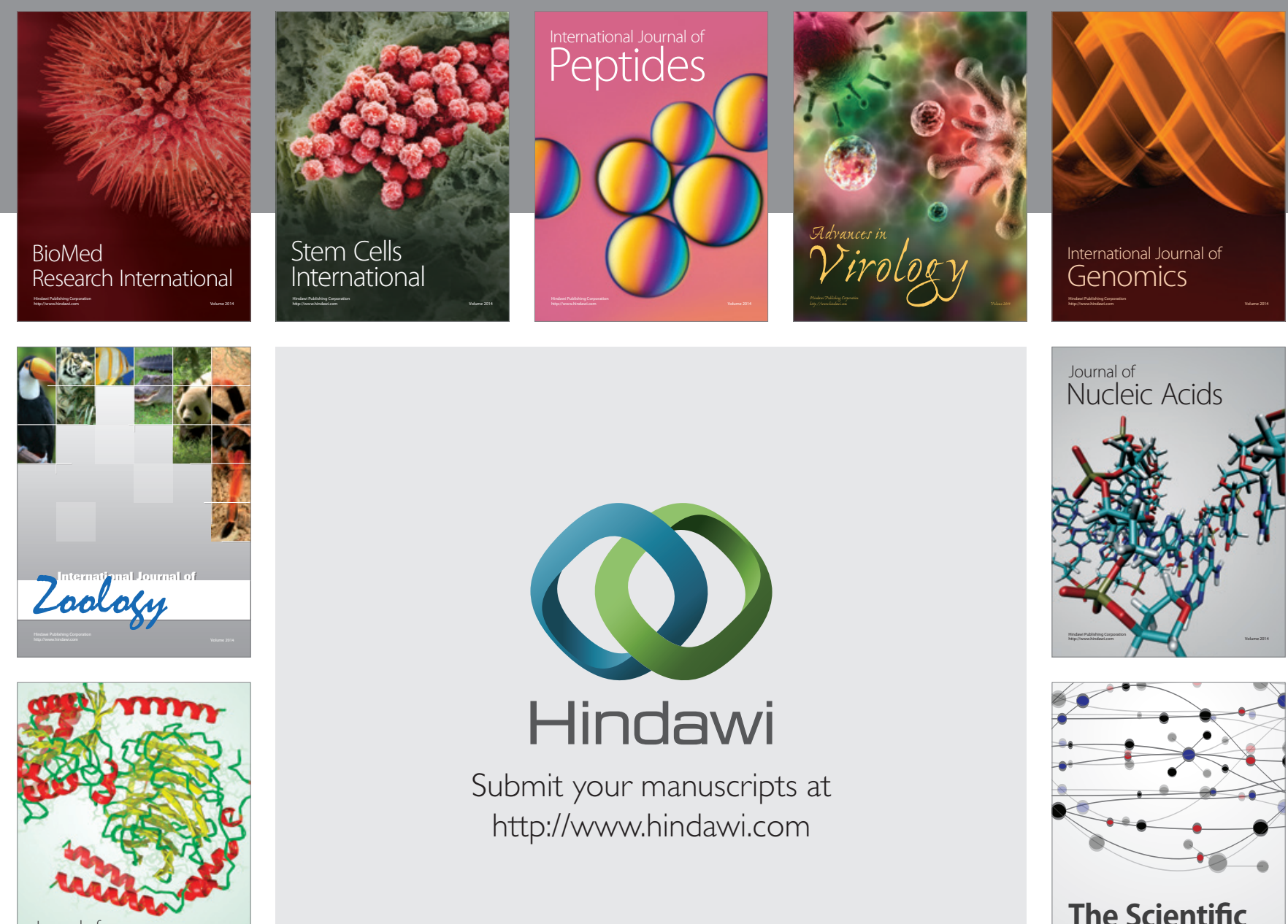

Submit your manuscripts at

http://www.hindawi.com

Journal of
Signal Transduction
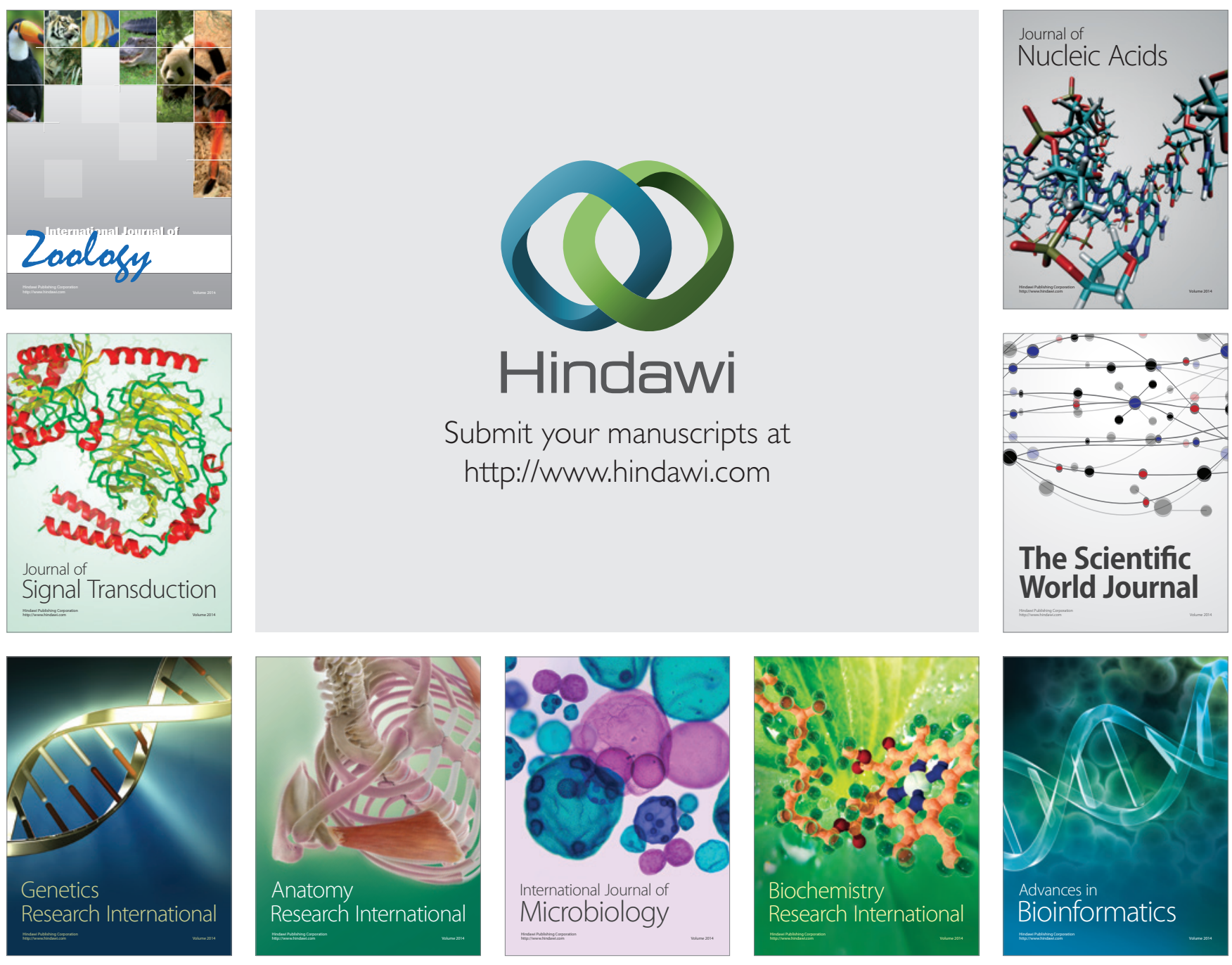

The Scientific World Journal
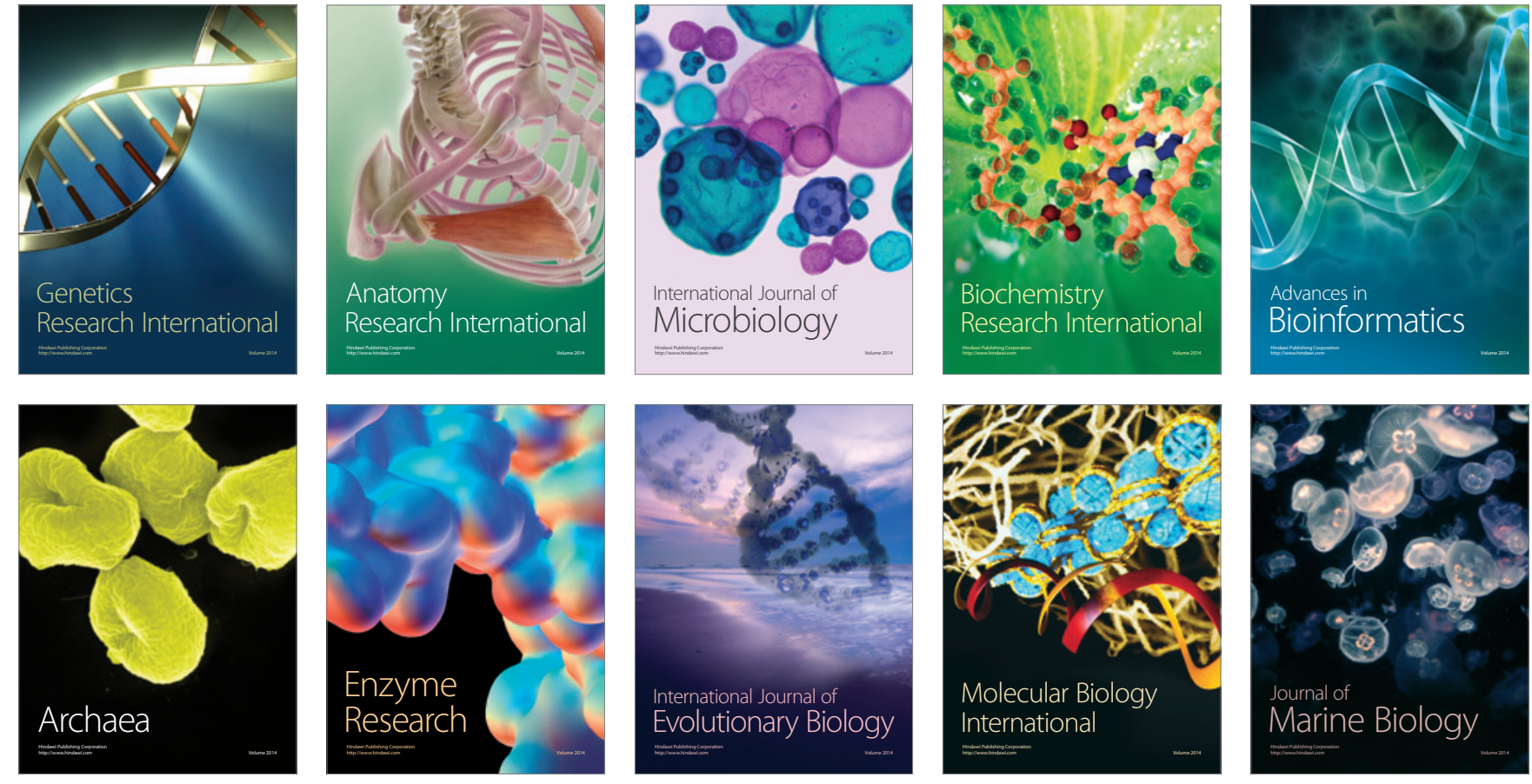